Provided for non-commercial research and education use. Not for reproduction, distribution or commercial use.

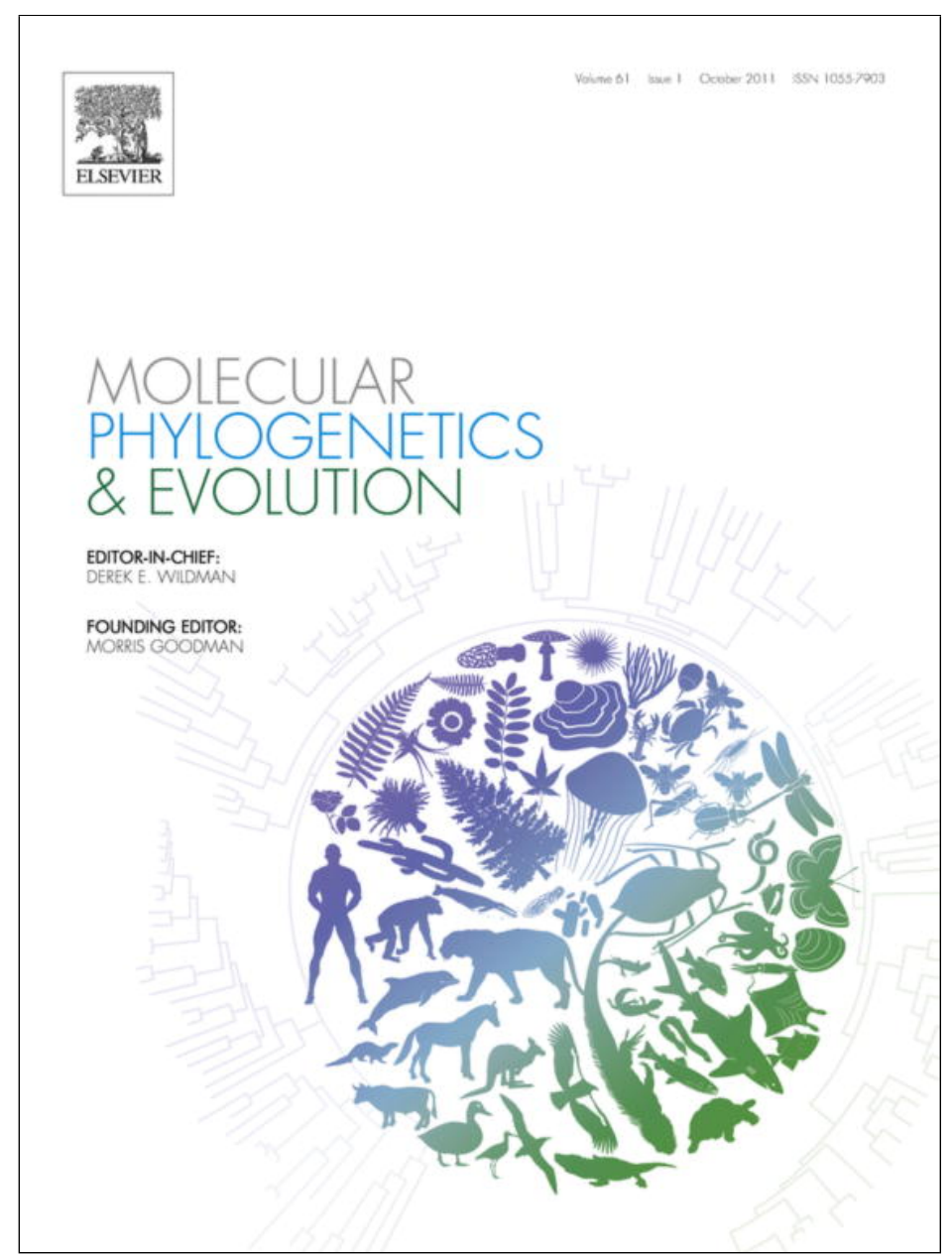

This article appeared in a journal published by Elsevier. The attached copy is furnished to the author for internal non-commercial research and education use, including for instruction at the authors institution and sharing with colleagues.

Other uses, including reproduction and distribution, or selling or licensing copies, or posting to personal, institutional or third party websites are prohibited.

In most cases authors are permitted to post their version of the article (e.g. in Word or Tex form) to their personal website or institutional repository. Authors requiring further information regarding Elsevier's archiving and manuscript policies are encouraged to visit:

http://www.elsevier.com/copyright 


\title{
Multilocus phylogenetic analysis of the genus Atherina (Pisces: Atherinidae)
}

\author{
S.M. Francisco ${ }^{\mathrm{a}, \mathrm{b}, *}$, L. Congiu $^{\mathrm{c}}$, S. von der Heyden ${ }^{\mathrm{d}}$, V.C. Almada ${ }^{\mathrm{a}}$ \\ ${ }^{a}$ Eco-Ethology Research Unit, ISPA-IU, Rua Jardim do Tabaco 34, 1149-041 Lisboa, Portugal \\ ${ }^{\mathrm{b}}$ Departamento de Zoologia e Antropologia, Faculdade de Ciências da Universidade do Porto, Praça Gomes Teixeira, 4099-002 Porto, Portugal \\ ${ }^{\mathrm{c}}$ Dipartamento di Biologia, Università di Padova, Via U. Bassi 58/B, 35121 Padova, Italy \\ ${ }^{\mathrm{d}}$ Evolutionary Genomics Group, University of Stellenbosch, Private Bag X1, Matieland 7602, South Africa
}

\section{A R T I C L E I N F O}

\section{Article history:}

Received 9 November 2010

Revised 3 June 2011

Accepted 4 June 2011

Available online 13 June 2011

\section{Keywords:}

Phylogeny

Atherina boyeri

Atherina presbyter

Atherina hepsetus

Atherina breviceps

Punctated and non-punctated forms

\begin{abstract}
A B S T R A C T
Sand-smelts are small fishes inhabiting inshore, brackish and freshwater environments and with a distribution in the eastern Atlantic and Mediterranean Sea, extending south into the Indian Ocean. Here, we present a broad phylogenetic analysis of the genus Atherina using three mitochondrial (control region, $12 \mathrm{~S}$ and 16S) and two nuclear markers (rhodopsin and 2nd intron of S7). Phylogenetic analyses fully support the monophyly of the genus. Two anti-tropical clades were identified, separating the South African Atherina breviceps from the north-eastern Atlantic and Mediterranean Atherina' species. In European waters, two groups were found. The first clade formed by a well supported species-pair: Atherina presbyter (eastern Atlantic) and Atherina hepsetus (Mediterranean), both living in marine waters; a second clade included Atherina boyeri (brackish and freshwater environments) and two independent lineages of marine punctated and non-punctated fishes, recently proposed as separate species. Sequence divergence values strongly suggest multiple species within the $A$. boyeri complex.
\end{abstract}

(c) 2011 Elsevier Inc. All rights reserved.

\section{Introduction}

Atheriniformes sensu Nelson (1994) are small inshore fish which typically spawn demersal eggs in shallow waters. They probably undertook several radiations in different continents and invaded brackish and freshwaters multiple times, giving rise to secondary freshwater taxa (Nelson, 1994). The genus Atherina Linnaeus (1758) (sand-smelts) is distributed in the eastern Atlantic Ocean, Mediterranean and Black Seas and extends south into the southern Atlantic and western Indian Ocean along the African coast (Quignard and Pras, 1986). Sand-smelts are small fishes inhabiting inshore marine environments as well as brackish and freshwater habitats. The taxonomy of this genus has been unstable due to both morphological character overlap among species and intra-specific variability in characters used in their classification. Kiener and Spillman (1969) published an extensive revision of the genus in the Mediterranean Sea and synonymised many of the nominal species, condensing two genera and 20 species to a single genus with three species: the Mediterranean sand-smelt Atherina hepsetus (Linnaeus 1758), the big-scale sand-smelt Atherina boyeri (Risso 1810) and the sand-smelt Atherina presbyter (Cuvier 1829). A. hepsetus is mainly restricted to the Mediterranean and Black Seas,

\footnotetext{
* Corresponding author at: Eco-Ethology Research Unit, ISPA-IU, Rua Jardim do Tabaco 34, 1149-041 Lisboa, Portugal. Fax: +351 218860954.

E-mail address: sara_francisco@ispa.pt (S.M. Francisco).
}

although it has also been reported in the eastern Atlantic coasts of Spain, Morocco, Madeira and Canary Islands (Quignard and Pras, 1986). The distribution of $A$. boyeri ranges from England and Netherlands to Mauritania and in waters around the Mediterranean and Black Seas (Quignard and Pras, 1986), whereas A. presbyter ranges from the southern North Sea and British Isles to the Canary Islands, Mauritania and Cape Verde. It has also been reported from the Azores archipelago (Santos et al., 1997) and, rarely, from the western Mediterranean (Kiener and Spillman, 1969; Quignard and Pras, 1986). From the African coast two additional species were described: Atherina lopeziana (Rossignol and Blanche 1961) which is confined to the Gulf of Guinea, and Atherina breviceps (Valenciennes 1835) which is abundant along the south east and west coasts of South Africa (Maugé, 1990).

Based on morphological and molecular characters, several authors proposed the recognition of different forms or species within what was formerly grouped under $A$. boyeri. This distinguished punctated (spotted) and non-punctated fishes, as well as those restricted to marine, brackish and freshwater habitats (e.g. Astolfi et al., 2005; Klossa-Kilia et al., 2002; Trabelsi et al., 2002a). Francisco et al. (2008) provided a comprehensive phylogenetic analysis of the eastern Atlantic and Mediterranean species of Atherina based on mitochondrial DNA, and revised their taxonomy, proposing three distinct species within the A. boyeri complex: A. boyeri (inhabiting lagoons and freshwater bodies), as well as "punctuated" and "non punctuated" forms (both typically present in marine conditions). 
As Francisco et al. (2008) based their inferences only on mtDNA, they could not test for reproductive isolation among sympatric species. Indeed, the possibility of hybridization between fish with very distinct mitochondrial haplotypes could not be ruled out, in particular those within the $A$. boyeri complex. In the present work we analyze 536 specimens of the three European recognized species and the southern African A. breviceps, providing a nearly complete phylogenetic coverage of the genus. Moreover, the use of three mitochondrial (control region, 12S and 16S) and two nuclear markers (rhodopsin and 2nd intron of S7) allows a more precise assessment of the degree of differentiation among the putative species of the $A$. boyeri complex.

\section{Materials and methods}

In this study we used specimens of $A$. presbyter $(N=176), A$. hepsetus $(N=34), A$. boyeri - including freshwater/brackish $(N=288)$, punctated $(N=12)$ and non-punctated fishes $(N=18)$, and $A$. breviceps $(N=5)$. Samples were collected from a variety of locations in Europe and South Africa and preserved in $96^{\circ}$ ethanol (Fig. 1, Table 1). A complete list of specimens used is provided in the electronic Supplementary material (Table S1). South African samples of Iso natalensis were included as outgroup in the molecular analyses.

Total genomic DNA of new individuals was extracted with REDExtract-N-ampl kit (Sigma-Aldrich), following the manufacturer instructions. Mitochondrial fragments of the control region (CR), $12 \mathrm{~S}$ rRNA and 16rRNA genes, and nuclear fragments of the rhodopsin gene and $\mathrm{S7}$ intron 2 were amplified and sequenced by polymerase chain reaction (PCR) (Table 2). Amplifications were conducted in $20 \mu \mathrm{l}$ total-reaction volume with $10 \mu \mathrm{l}$ of REDExtract-N-ampl PCR reaction mix (Sigma-Aldrich), 0.8 of each primer $(10 \mu \mathrm{M}), 4.4 \mu \mathrm{l}$ of sigma-water and $4 \mu \mathrm{l}$ of template DNA.

Purification and sequencing were performed as services by Stabvida (Oeiras, Portugal), and details on these procedures may be requested from the authors. The sequences were aligned with Clustal X2 (Larkin et al., 2007) and CodonCode Aligner v.3.5.6. (CodonCode Corporation, MA, USA), and corrected by eye. For the nuclear fragments, the double peaks in chromatograms generated as artefacts in the vicinity of heterozygous indels were used to identify the specific strands of the fragment, following the approach of Sousa-Santos et al. (2005). Single polymorphisms were manually assigned recovering both strands. In addition to the alignments for each gene, all five were combined into a concatenated alignment. The alignments were deposited in TreeBase (http://www.treebase.org, submission ID number 11577).

jmodeltest 3.7 (Guindon and Gascuel, 2003; Posada, 2008) with the Akaike Information Criterion (AIC) was used to identify the best-fit model of evolution for each fragment: $\operatorname{TrN}+G$ for CR (gamma distribution shape parameter $G=0.4154$ ), $T r N e f+I+G$ for $12 S$ (proportion of invariable sites $I=0.5866, G=0.7196$ ), TVMef $+I+G$ for $16 \mathrm{~S}(I=0.5292, G=0.8968)$, HKY $+I$ for rhodopsin $(I=0.7038)$, and $\operatorname{TrNef}+G$ for $S 7(G=0.4235)$. For the concatenated data the most appropriate model was GTR $+I+G(I=0.4825, G=0.6393)$.

PAUP* 4.0b10 (Swofford, 2000) was used to carry out phylogenetic analyses using Maximum Parsimony (MP) approach with heuristic search and neighbor-joining (NJ) method with the selected models of evolution for the six datasets (five markers and concatenated dataset). The robustness of the inferred trees was tested by 500 bootstrap replicates (Felsenstein, 1985).

Maximum likelihood (ML) analyses were performed with RAxML v7.0.3 (Stamatakis, 2006) via Cipres (Miller et al., 2010). The concatenated dataset was partitioned by gene, and number of invariant sites and gamma shape parameters were calculated separately for each partition. Node support was estimated with 100 bootstrap replicates.
Bayesian analyses were implemented in MrBayes 3.2 (Huelsenbeck and Ronquist, 2001; Ronquist and Huelsenbeck, 2003). Sequences were partitioned by region (five fragments) and codon position (rhodopsin). Posterior probabilities were determined from four independent runs of two million generations of Markov chain Monte Carlo (MCMC) simulations. Topologies were sampled every 1000 generations, and a majority-rule consensus tree was estimated after discarding the first 2000 sampled generations.

For each fragment, Kishino-Hasegawa test (K-H) (Kishino and Hasegawa, 1989) and Shimodaira-Hasegawa test (S-H) (Shimodaira and Hasegawa, 1999) were performed to test whether specific topologies resulting from the above analyses were significantly better than competing topologies (with constraints to the topologies recovered with the concatenated dataset). Both tests were performed with PAUP*, using the re-sampling estimated loglikelihood (RELL) approach with 1000 bootstrap replications.

The software package Arlequin 3.5 (Excoffier et al., 2005) was used to estimate the corrected average pairwise differences among Atherina species for the five individual markers, using the TamuraNei model (Tamura and Nei, 1993). Taking into account the fragment size, the percentage of divergence between species was also computed.

\section{Results}

In total, $353 \mathrm{bp}$ were sequenced from the $12 \mathrm{~S}, 470 \mathrm{bp}$ from the $16 \mathrm{~S}, 379 \mathrm{bp}$ from the CR, 455 from the rhodopsin and 224 from the S7 (including indels), yielding 72, 106, 527, 53 and 119 haplotypes, respectively (Tables S1-S6 in supplementary materials).

Phylogenetic analyses of the concatenated fragments (1705 bp) converged on a similar tree topology (Fig. 2). The phylogeny provided support for the monophyly of the genus (posterior probability - $\mathrm{pp}=1$ ), as well as for the monophyly of each species: A. presbyter, $A$. hepsetus, A. boyeri, non-punctated fish, punctated fish and $A$. breviceps (Fig. 2). For Atherina, two major clades were found: one corresponding to the South African A. breviceps ( $\mathrm{pp}=1)$ and the other one clustering together the five European species $(\mathrm{pp}=1)$. Within the European samples, two strongly supported sister groups were found: a first group comprising two clades corresponding to $A$. presbyter and $A$. hepsetus ( $\mathrm{pp}=1$ ), and a second group with the remaining three species, generally belonging to the $A$. boyeri complex ( $\mathrm{pp}=0.98)$. Within this clade the non-punctated fish ( $\mathrm{pp}=1)$ appear as sister group to the remaining two species $(\mathrm{pp}=1)$. The latter clusters A. boyeri $(\mathrm{pp}=1)$ and punctated fish $(\mathrm{pp}=1)$ (Fig. 2$)$. At the intraspecific level it is possible to distinguish among continental $(\mathrm{pp}=1)$ and insular $(\mathrm{pp}=1)$ A. presbyter, and between Azores and Canaries within the latter, suggesting genetically structured populations. For $A$. boyeri, the haplotypes from Atlantic and Mediterranean locations are separated ( $\mathrm{pp}=0.98$ and 1, respectively) (Fig. 2). Furthermore, MP, NJ, ML and Bayesian analysis of the five individual fragments yielded congruent, yet not as informative, trees (Table S7). The results of the $\mathrm{K}-\mathrm{H}$ and $\mathrm{S}-\mathrm{H}$ tests suggested that the trees recovered for each gene were not significantly better than the constrained gene tree (Table S8), with the following exceptions: MP, NJ and BA for 16S, and ML for rhodopsin.

Table 3 shows the divergence within species (diagonal) and among species after correction for within species variation (bellow diagonal), with every value being statistically significant $(P<0.05)$. The analysis of this table clearly shows that, for every marker analyzed and for the concatenated dataset, interspecific differences are clearly higher then intra-specific ones. A. presbyter and A. hepsetus clearly show less divergence among individuals, with the results for the three mitochondrial markers and rhodopsin corroborating the phylogenetic analyses. The exception is for S7 intron, which yielded the smallest percentage of divergence between punctated and non-punctated fish. The species status of the three Mediterra- 


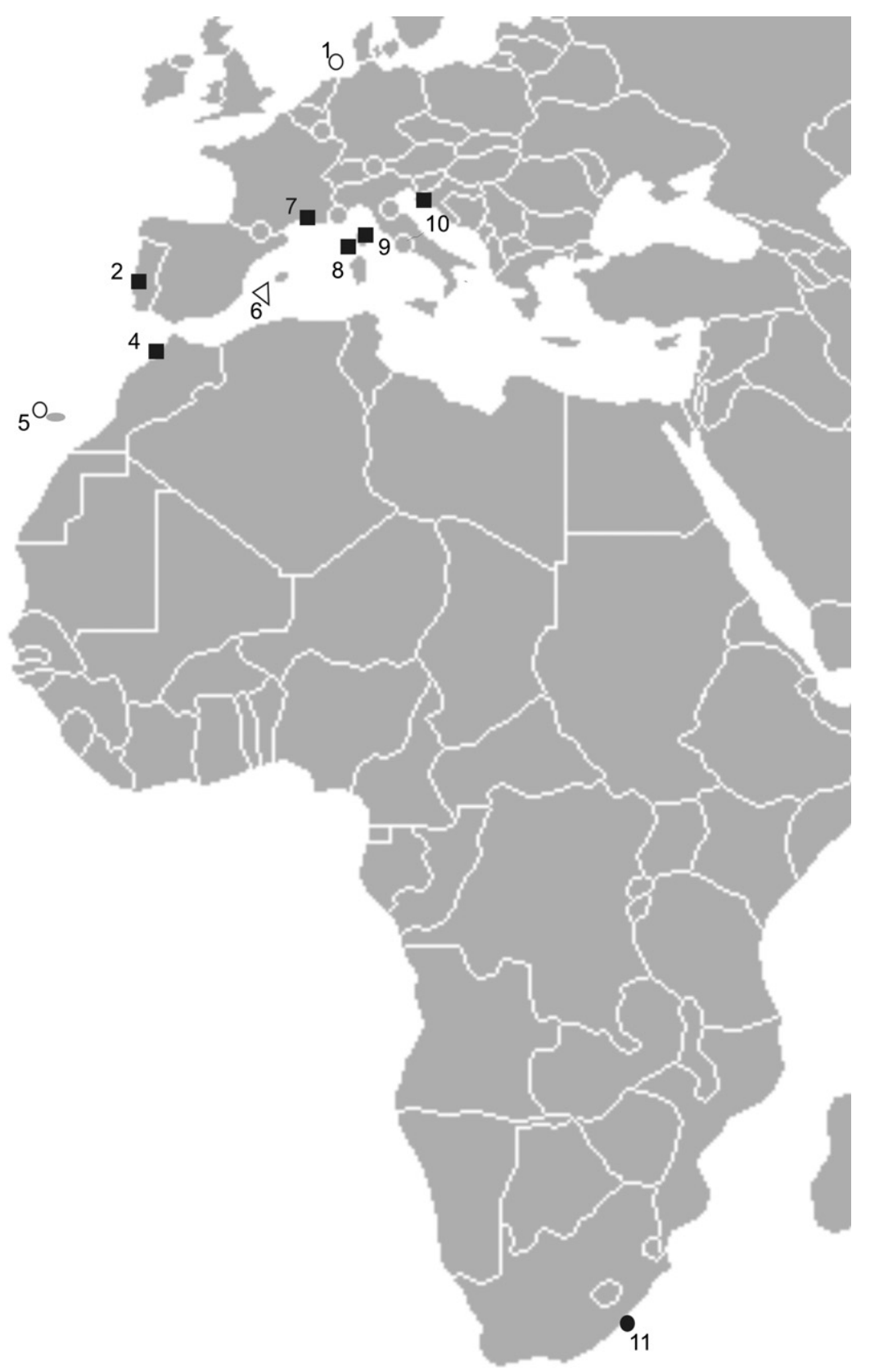

Fig. 1. Map of sampling locations for the concatenated data of Atherina: A. presbyter - white circle; A. boyeri complex - black square; A. hepsetus - white triangle; A. breviceps black circle. 1 Wadden Sea. 2 Almonda. 3 Azores. 4 Morocco. 5 Tenerife. 6 Formentera. 7 Thau. 8 Scandola. 9 Lavezzi. 10 Croatia. 11 South Africa.

nean types traditionally included in the $A$. boyeri complex is also reinforced by these results. Indeed, the percentage of divergence between $A$. boyeri and the punctated and non-punctated forms is roughly of the same magnitude as the values separating $A$. boyeri from $A$. presbyter and $A$. hepsetus. These values are higher for all markers than those separating the two recognized species $A$. hepsetus and A. presbyter (Table 3).

\section{Discussion}

The present paper added additional species and three new markers (one mitochondrial and two nuclear ones) confirming and expanding the results of Astolfi et al. (2005) and Francisco et al. (2008). The monophyly of the genus was fully supported.

Two anti-tropical clades were identified: one with the South African A. breviceps and another comprising the fish from the north-eastern Atlantic and Mediterranean. The last clade includes one well supported species pair: A. presbyter in the eastern Atlantic and $A$. hepsetus in the Mediterranean, both species living in marine waters. Sister to this group is a clade formed by A. boyeri (a fish inhabitting brackish and freshwater environments around the Mediterranean and scattered locations in west Europe) and the two marine punctated and non-punctated fish, only known from the Mediterranean. The three forms of this complex show clear genetic differentiation, both for the mitochondrial and the nuclear markers, which supports species status for the punctated and for the non-punctated forms, thus restricting the A. boyeri sensu strict to lagoons, estuaries, lakes and rivers. The distinctiveness of the three species of the A. boyeri complex is consistent across the whole Mediterranean, both in the eastern and western basins, and their genetic divergences are comparable with those found between A. presbyter/hepsetus and A. boyeri. These findings are consis- 
Table 1

Collection sites and number of Atherina individuals used in the present work.

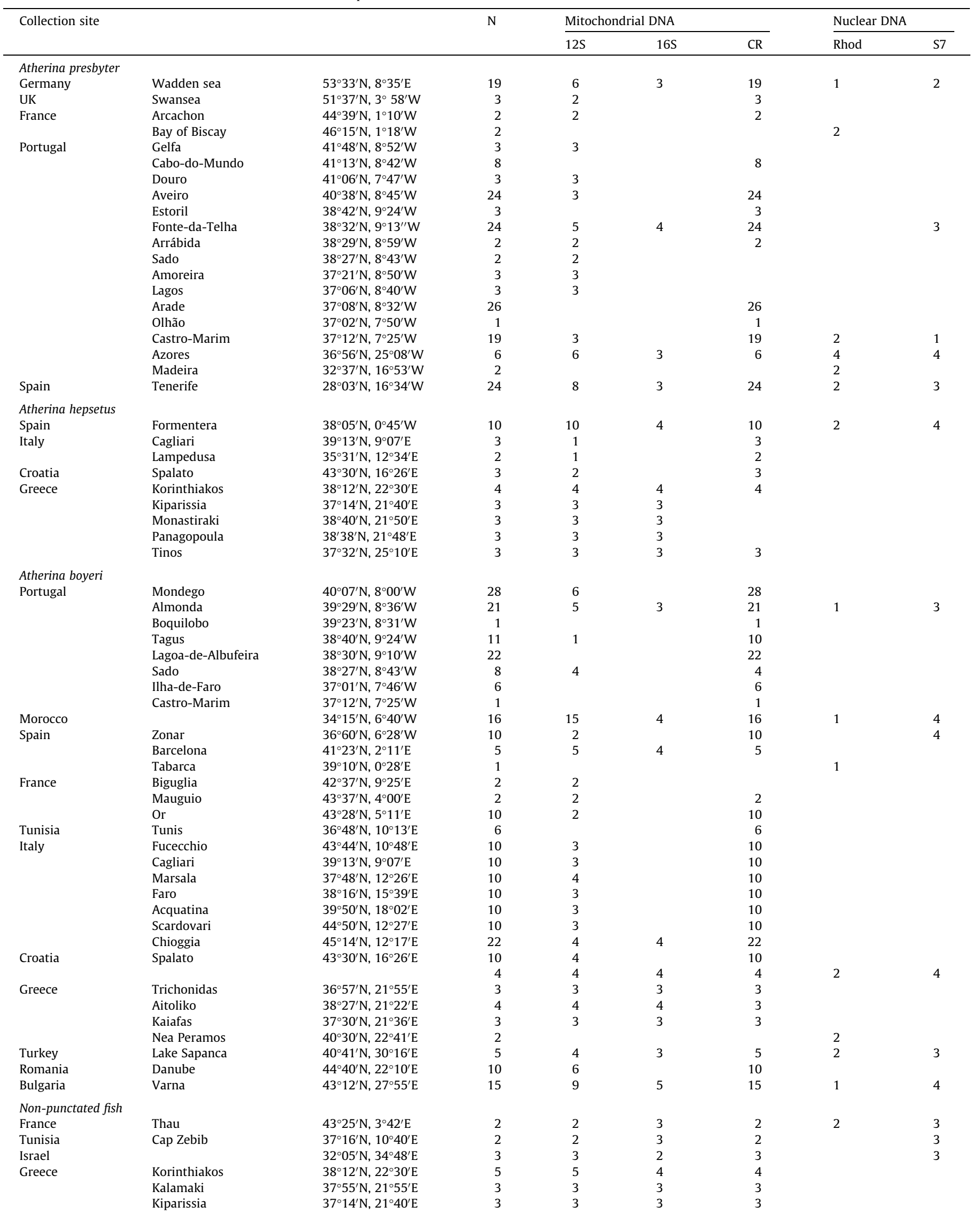


Table 1 (continued)

\begin{tabular}{|c|c|c|c|c|c|c|c|c|}
\hline \multirow[t]{2}{*}{ Collection site } & & & \multirow[t]{2}{*}{$\mathrm{N}$} & \multicolumn{3}{|c|}{ Mitochondrial DNA } & \multicolumn{2}{|c|}{ Nuclear DNA } \\
\hline & & & & $12 \mathrm{~S}$ & $16 S$ & $\mathrm{CR}$ & Rhod & S7 \\
\hline \multicolumn{9}{|l|}{ Punctated fish } \\
\hline \multirow[t]{3}{*}{ France } & Lavezzi & $41^{\circ} 19^{\prime} \mathrm{N}, 9^{\circ} 16^{\prime} \mathrm{E}$ & 4 & 2 & 2 & 3 & 4 & 4 \\
\hline & Scandola & $42^{\circ} 25^{\prime} \mathrm{N}, 8^{\circ} 34^{\prime} \mathrm{E}$ & 3 & 2 & 2 & 3 & 3 & 3 \\
\hline & Agde & $43^{\circ} 19^{\prime} \mathrm{N}, 3^{\circ} 28^{\prime} \mathrm{E}$ & 3 & 2 & 3 & 2 & 3 & 3 \\
\hline Tunisia & Hergla & $36^{\circ} 02^{\prime} \mathrm{N}, 10^{\circ} 30^{\prime} \mathrm{E}$ & 2 & 2 & & 2 & & \\
\hline \multicolumn{9}{|c|}{ Atherina breviceps } \\
\hline South Africa & Sezela & $30^{\circ} 41^{\prime} \mathrm{S}, 30^{\circ} 24^{\prime} \mathrm{E}$ & 5 & 5 & 5 & 5 & 1 & 4 \\
\hline \multicolumn{9}{|l|}{ Iso natalensis } \\
\hline South Africa & Durban & $29^{\circ} 51^{\prime} \mathrm{S}, 31^{\circ} 01^{\prime} \mathrm{E}$ & 5 & 5 & 5 & 5 & 2 & 3 \\
\hline
\end{tabular}

Table 2

Primers and polymerase chain reaction conditions for each fragment.

\begin{tabular}{|c|c|c|c|c|}
\hline Fragment & Primer name & Sequence & Source & PCR conditions \\
\hline \multirow[t]{2}{*}{ Control region } & L-pro1 & 5' АСТСТСАССССТАGCTCCСAAAG 3' & Ostellari et al. 1996 & $94^{\circ} \mathrm{C} 2^{\prime}$ \\
\hline & H-DL1 & $5^{\prime}$ CCTGAAGTAGGAACCAGATGCCAG $3^{\prime}$ & & $\begin{array}{l}35 \times\left(94^{\circ} \mathrm{C} 30^{\prime \prime}, 55^{\circ} \mathrm{C} 30^{\prime \prime}, 72^{\circ} \mathrm{C} 1^{\prime}\right) \\
72^{\circ} \mathrm{C} 5^{\prime}\end{array}$ \\
\hline \multirow[t]{2}{*}{$12 S$} & 12SFor & 5' AACTGGGATTAGATACCCCAC 3' & Almada et al. 2005 & $94^{\circ} \mathrm{C} 3^{\prime}$ \\
\hline & 12SRev & 5' GGGAGAGTGACGGGCGGTGTG 3' & & $\begin{array}{l}35 \times\left(94^{\circ} \mathrm{C} 45^{\prime \prime}, 50^{\circ} \mathrm{C} 1^{\prime}, 72^{\circ} \mathrm{C} 1^{\prime}\right) \\
72^{\circ} \mathrm{C} 10^{\prime}\end{array}$ \\
\hline \multirow[t]{2}{*}{$16 S$} & 16SFor & 5' AAGCCTCGCCTGTTTACCAA 3' & Almada et al. 2005 & $94^{\circ} \mathrm{C} 3^{\prime}$ \\
\hline & 16SRev & $5^{\prime}$ CTGAACTCAGATCACGTAGG $3^{\prime}$ & & $\begin{array}{l}35 \times\left(94^{\circ} \mathrm{C} 45^{\prime \prime}, 50{ }^{\circ} \mathrm{C} 1^{\prime}, 72^{\circ} \mathrm{C} 1^{\prime}\right) \\
72^{\circ} \mathrm{C} 10^{\prime}\end{array}$ \\
\hline \multirow[t]{2}{*}{ Rhodopsin } & Rod-F2B & 5' GTCTGCAAGCCCATCAGCAACTTCCG 3' & Sevilla et al. 2007 & $94^{\circ} \mathrm{C} 3^{\prime}$ \\
\hline & Rod-5R & 5' GGTGGTGATCATGCAGTGGCGGAA 3' & & $\begin{array}{l}40 \times\left(92^{\circ} \mathrm{C} 30^{\prime \prime}, 60^{\circ} \mathrm{C} 1^{\prime}, 72^{\circ} \mathrm{C} 30^{\prime \prime}\right) \\
72^{\circ} \mathrm{C} 7^{\prime}\end{array}$ \\
\hline \multirow[t]{2}{*}{ S7 intron 2} & S7RPEX2F & $5^{\prime}$ AGCGCCAAAATAGTGAAGCC $3^{\prime}$ & Chow and Hazama 1998 & $94{ }^{\circ} \mathrm{C} 2^{\prime}$ \\
\hline & S7RPEX3R & 5' GCCTTCAGGTCAGAGTTCAT 3' & & $\begin{array}{l}40 \times\left(95^{\circ} \mathrm{C} 45^{\prime \prime}, 52^{\circ} \mathrm{C} 1^{\prime}, 72^{\circ} \mathrm{C} 45^{\prime}\right) \\
72^{\circ} \mathrm{C} 10^{\prime}\end{array}$ \\
\hline
\end{tabular}

tent with the findings by Trabelsi et al. based on biometrical characters (2002b) and the cytochrome b gene (2002a), although these authors restricted their analyses to comparisons involving fish from Tunisia and France. Astolfi et al. (2005) and Francisco et al. (2008) confirmed these results with additional mtDNA fragments. Moreover, the present results reveal a closer relationship between brackish/lagoon $A$. boyeri and punctated fish, with this group being sister to non-punctated specimens. In their analysis of portion of the mitochondrial cytochrome b, Milana et al. (2008) detected the presence of an insertion, common to lagoon and punctuated forms of $A$. boyeri. The agreement between biometric and genetic characters (both mitochondrial and nuclear) and the wide distribution of the three entities represent, in our view, very strong support for the recognition of three different species. Because of the very large number of specific names and the need to examine specimens dispersed in several museums, the formal re-description of species is beyond the scope of the present paper, but we argue for the urgent need to undertake this. To avoid confusion, it is important to state that, for the time being, we restricted the name Atherina boyeri to the species inhabiting brackish and freshwaters, corresponding to with Trabelsi et al.'s (2002a,b) use of Atherina lagunae. The validity of species names in this complex is however not assured by formal taxonomical procedures.

At a larger scale, the present results raise two interesting biogeographical questions. One is the emergence of two antitropically distributed sister clades. The impossibility of getting samples from $A$. lopeziana precludes further interpretation, as this anti-tropical distribution of clades may be an artifact caused by the absence of the tropical species. However, A. breviceps from southern Africa appears to be the earliest diverging atherinid lineage (Fig. 2), which suggests several possible evolutionary scenarios. The first postulates that $A$. breviceps, or an ancestor of this species, had a distribution which included the northern and southern Atlantic and that subsequent extirpation events in its northern distribution left only a remnant population in southern Africa. Several extant fish species have anti-tropical Atlantic distributions, e.g. orange roughy, Hoplostethus atlanticus (Maul, 1986), the canary drum, Umbrina canariensis (Chao and Trewavas, 1990) and the sand-steenbras, Lithognathus mormyrus (Bauchot and Hureau, 1990), so this is a distinct possibility. Secondly, a southern atherinid species might have colonized northern European waters. Support for this hypothesis requires further analysis, as most marine colonizations probably occurred from north to south, e.g. Cape hake, Merluccius (von der Heyden et al., 2007), anchovies, Engraulis spp. (Grant and Bowen, 2006) and Palinurus lobsters (Groeneveld et al., 2007).

A second aspect emerging from this study is the species richness of the Mediterranean Atherina and their likely origin inside the Mediterranean itself. Of the six species analyzed, four are found in the Mediterranean. One, A. hepsetus, is sister species to the Atlantic A. presbyter and, judging from the molecular divergence values (Table 3 ), is a relatively recent example of vicariance separating the Atlantic A. presbyter and the Mediterranean A. hepsetus. In the clade comprising $A$. boyeri, two species are restricted to the marine waters of the Mediterranean, while A. boyeri, although present in West Europe, is much more diverse in the Mediterranean and Black Seas (Francisco et al., 2008). In glacial conditions it is likely that this species survived in the Mediterranean area, re-colonizing West Europe during the present interglacial. Thus, the Mediterranean likely promoted several instances of speciation in different clades of Atherina at different times: a more recent event for $A$. presbyter/A. hepsetus, and two more ancient ones in the $A$. boyeri complex. It is becoming increasingly evident that the Mediterranean promoted the diversification of a number of fish 


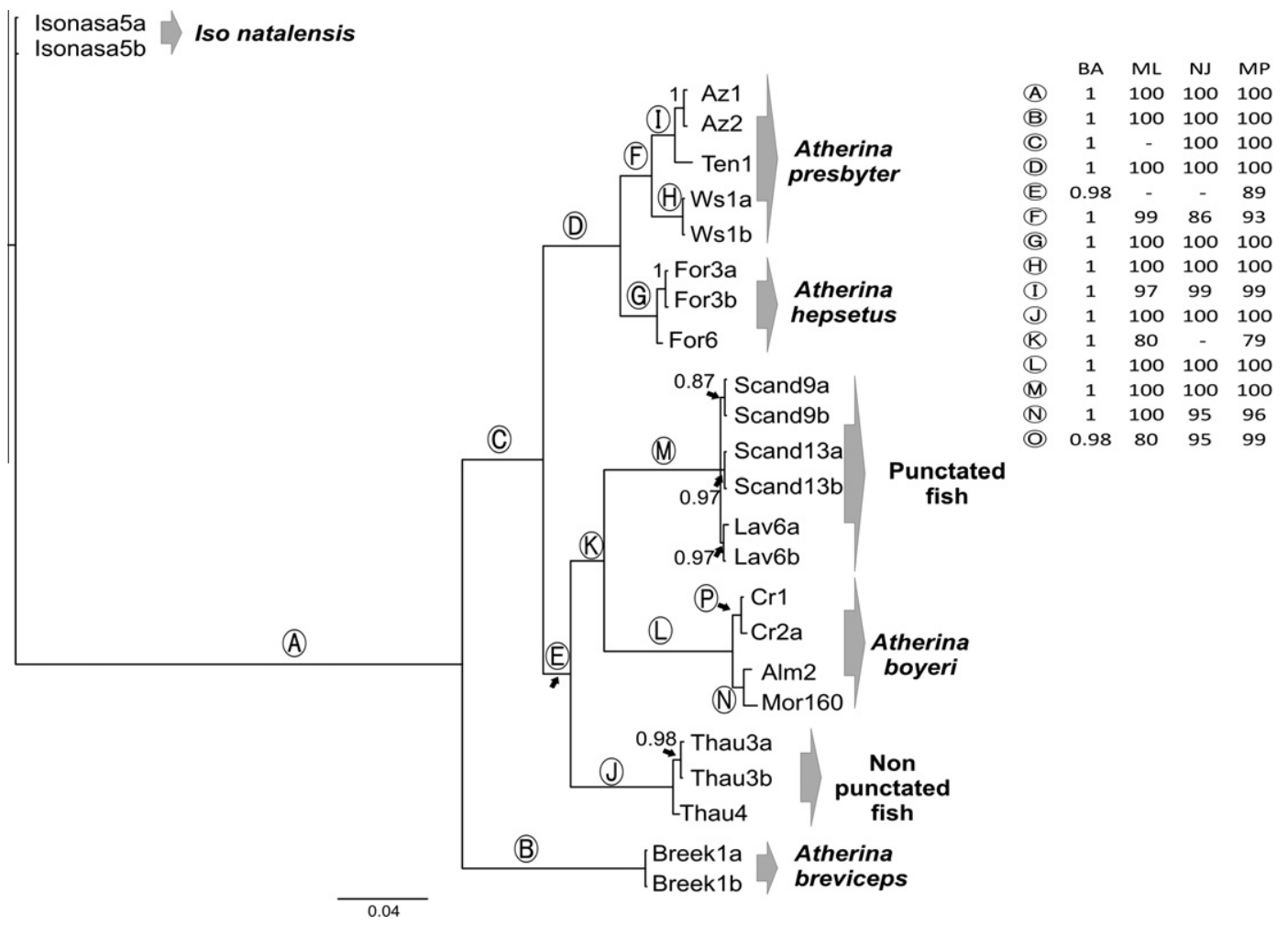

Fig. 2. Phylogenetic relationships within Atherina for the concatenated data of $12 \mathrm{~S}, 16 \mathrm{~S}$, mitochondrial control region, rhodopsin and second intron of S7. Each main node is represented by circled capital letters. Embebbed table: BA - Bayesian analysis, MP - maximum parsimony, NJ -neighbor joining and ML - maximum likelihood. For phylogenetic analyses is shown the support for each node (posterior probabilities $>75$ for Bayesian inference and bootstrap $>0.75$ for other approaches).

Table 3

Divergence among species after correction for within species variation, based on corrected average pairwise differences. Within species pairwise differences are shown in the diagonal.

\begin{tabular}{|c|c|c|c|c|c|c|}
\hline & A. presbyter & A. hepsetus & A. boyeri & Punctated fish & Non-punctated fish & A. breviceps \\
\hline \multicolumn{7}{|l|}{$12 S$} \\
\hline A. presbyter & 0.90 & & & & & \\
\hline A. hepsetus & 1.00 & 0.14 & & & & \\
\hline A. boyeri & 4.19 & 5.20 & 0.87 & & & \\
\hline Punctated fish & 4.14 & 5.22 & 6.50 & 0.35 & & \\
\hline Non-punctated fish & 3.39 & 4.18 & 3.92 & 4.73 & 0.18 & \\
\hline A. breviceps & 4.38 & 5.02 & 6.09 & 5.37 & 4.89 & 0.52 \\
\hline \multicolumn{7}{|l|}{$16 S$} \\
\hline A. presbyter & 1.06 & & & & & \\
\hline A. hepsetus & 1.33 & 0.38 & & & & \\
\hline A. boyeri & 8.54 & 8.44 & 2.12 & & & \\
\hline Punctated fish & 8.82 & 9.52 & 8.88 & 0.35 & & \\
\hline Non-punctated fish & 7.79 & 7.91 & 8.27 & 9.09 & 0.65 & \\
\hline A. breviceps & 11.44 & 11.81 & 11.61 & 11.48 & 12.55 & 0.94 \\
\hline \multicolumn{7}{|l|}{$C R$} \\
\hline A. presbyter & 4.85 & & & & & \\
\hline A. hepsetus & 7.92 & 1.69 & & & & \\
\hline A. boyeri & 21.15 & 23.46 & 5.16 & & & \\
\hline Punctated fish & 23.74 & 28.33 & 22.29 & 1.44 & & \\
\hline Non-punctated fish & 19.28 & 16.84 & 16.95 & 22.98 & 1.60 & \\
\hline A. breviceps & 23.07 & 25.24 & 27.89 & 29.23 & 25.77 & 3.96 \\
\hline \multicolumn{7}{|c|}{ Mitochondrial concatenated } \\
\hline A. presbyter & 2.10 & & & & & \\
\hline A. hepsetus & 3.22 & 0.72 & & & & \\
\hline A. boyeri & 10.61 & 11.47 & 2.63 & & & \\
\hline Punctated fish & 10.88 & 12.61 & 11.62 & 0.17 & & \\
\hline Non-punctated fish & 9.57 & 9.12 & 9.51 & 11.76 & 0.83 & \\
\hline A. breviceps & 11.84 & 12.88 & 13.40 & 14.35 & 13.66 & 1.74 \\
\hline \multicolumn{7}{|l|}{ Rhod } \\
\hline A. presbyter & 0.17 & & & & & \\
\hline A. hepsetus & 0.47 & 0.00 & & & & \\
\hline
\end{tabular}


Table 3 (continued)

\begin{tabular}{|c|c|c|c|c|c|c|}
\hline & A. presbyter & A. hepsetus & A. boyeri & Punctated fish & Non-punctated fish & A. breviceps \\
\hline A. boyeri & 1.30 & 1.77 & 0.06 & & & \\
\hline Punctated fish & 1.22 & 1.62 & 1.57 & 0.48 & & \\
\hline Non-punctated fish & 1.17 & 1.57 & 0.60 & 0.94 & 0.00 & \\
\hline A. breviceps & 0.94 & 1.35 & 1.82 & 1.58 & 1.58 & 0.00 \\
\hline \multicolumn{7}{|l|}{ S7 } \\
\hline A. presbyter & 0.54 & & & & & \\
\hline A. hepsetus & 0.53 & 0.72 & & & & \\
\hline A. boyeri & 1.65 & 1.26 & 2.80 & & & \\
\hline Punctated fish & 1.15 & 0.39 & 0.63 & 0.31 & & \\
\hline Non-punctated fish & 1.41 & 1.03 & 0.35 & 0.10 & 0.41 & \\
\hline A. breviceps & 6.35 & 5.93 & 7.29 & 6.24 & 6.80 & 0.15 \\
\hline
\end{tabular}

groups, e.g. Microlipophrys (Almada et al., 2005), Symphodus (Almada et al., 2002), Diplodus (Hanel and Sturmbauer, 2000), Sparidae (Herrán et al., 2001). As some members of the clades were able to move into Atlantic waters adjacent to the Mediterranean, they are not considered Mediterranean endemics, which means that the level of endemism under-represents the role of the Mediterranean in the generation of new species. In the case of Atherina, we suggest that the origin of species in the A. boyeri complex may date back to the Messinian Salinity Crisis (MSC). Although no molecular clock specific for the Atherinidae is available, the divergence values presented in Table 3 are in the order of 4-6.5\% (12S), $8-9 \%(16 S)$ and $17-23 \%(C R)$, not in consistence with the divergence of $2-3.6 \%$ per million years frequently used for the mtDNA of fish (Brown and Wilson, 1979; Donaldson and Wilson, 1999, respectively). Thus, the scenario of speciation events around 5 million years ago seems plausible. During the MSC the Mediterranean Sea suffered not only a drastic reduction in available marine habitat, but was fragmented into a number of water bodies that ranged in salinity from brackish to hypersaline (Hsü et al., 1977). As species of Atherina tend to tolerate wide ranges of salinity and temperature, it seems reasonable to hypothesize that populations separated by disjunct water bodies could have evolved into the distinct extant species recognized today. These became sympatric when the Mediterranean filled with Atlantic waters at the end of the crisis. Thus, it seems likely that the invasion of freshwater, with all the inherent adaptive and phenotypic changes, has occurred only once in the history of the genus Atherina.

The separation of the ancestors of $A$. presbyter in the Atlantic and $A$. hepsetus in the Mediterranean is certainly younger than ancestors of the $A$. boyeri complex judging from the divergence values found, and may have been triggered by glacial events at the early Pleistocene, separating warm waters of the Mediterranean from those of the Atlantic. As the divergence between the two species is too great, it is unlikely that the last glacial maximum played a significant role in the vicariance of the species.

The present study represents the most thorough investigation of the phylogeny of the genus Atherina for both the number of species studied and the variety of markers analyzed. The results support those previously obtained with mtDNA and provide clear-cut evidence of the need for a systematic revision of the genus. Moreover, the existence of three different species with good geographical and ecological overlap makes this genus potentially very interesting for tracing the history of postglacial Mediterranean colonizations. In this perspective a future insight into their phylogeographical history is strongly recommended.

\section{Acknowledgments}

We acknowledge Grant to S.M.F. (SFRH/BD/12653/2003) from FCT. The UIE-ISPA is funded by FCT through the pluri-annual and programmatic funding scheme (FEDER) as research unit \#331/94.
This work was also funded by MARIN-ERA/MAR/0001/2008. The authors are grateful to $S$. Chenu for her help with the laboratory work. Many thanks to Allan Connell who helped sample A. breviceps and I. natalensis.

\section{Appendix A. Supplementary material}

Supplementary data associated with this article can be found, in the online version, at doi:10.1016/j.ympev.2011.06.002.

\section{References}

Almada, F., Almada, V., Guillemaud, T., Wirtz, P., 2005. Phylogenetic relationships of the north-eastern Atlantic and Mediterranean blenniids. Biol. J. Linn. Soc. 86, 283-295.

Almada, V., Almada, F., Henriques, M., Santos, R.S., Brito, A., 2002. On the phylogenetic affinities of Centrolabrus trutta and Centrolabrus caeruleus (Perciformes: Labridae) to the genus Symphodus: molecular, meristic and behavioural evidences. Arquipélago. Life Mar. Sci. 19A, 85-92.

Astolfi, L., Dupanlouop, I., Rossi, R., Bisol, P.M., Faure, E., Congiu, L., 2005. Mitochondrial variability of sand smelt (Atherina boyeri, Risso 1810) populations from North Mediterranean coastal lagoons. Mar. Ecol. Prog. Ser. 297, 233-243.

Bauchot, M.L., Hureau, J.C., 1990. Sparidae. In: Quire, J.C., Hureau, J.C., Karrer, C., Post, A., Saldanha, L. (Eds.), Check-list of the Fishes of the Eastern Tropical Atlantic (CLOFETA), vol. 2. Paris. pp. 790-812.

Brown, W.M., Wilson, G.M., 1979. Rapid evolution of animal mitochondrial DNA. Proc. Natl. Acad. Sci. USA 76, 1967-1971.

Chao, L.N., Trewavas, E., 1990. Sciaenidae. In: Quire, J.C., Hureau, J.C., Karrer, C., Post, A., Saldanha, L. (Eds.), Check-List of the Fishes of the Eastern Tropical Atlantic (CLOFETA), vol. 2. Paris. pp. 813-826.

Chow, S., Hazama, K., 1998. Universal PCR primers for S7 ribosomal protein gene introns in fish. Mol. Ecol. 7, 1247-1263.

Donaldson, K.A., Wilson, R.W., 1999. Amphi-panamaic germinates of snook (Percoidei: Centropomidae) provide a calibration of the divergence rate in the mitochondrial DNA control region of fishes. Mol. Phylogenet. Evol. 13, 208-213.

Excoffier, L., Laval, G., Schneider, S., 2005. Arlequin ver 3.0: an integrated software package for population genetics data analysis. Evol. Bioinform. Online 1, 47-50.

Felsenstein, J., 1985. Confidence limits on phylogenies: an approach using the bootstrap. Evolution 39, 783-791.

Francisco, S.M., Congiu, L., Stefanni, S., Castilho, R., Brito, A., Ivanova, P.P., Levy, A., Cabral, H., Kilias, G., Doadrio, I., Almada, V.C., 2008. Phylogenetic relationships of the north-eastern Atlantic and Mediterranean forms of Atherina (Pisces, Atherinidae). Mol. Phylogenet. Evol. 48, 782-788.

Grant, W.S., Bowen, B.W., 2006. Living in a tilted world: climate change and geography limit speciation in Old World anchovies (Engraulis; Engraulidae). Mol. Phylogenet. Evol. 88, 673-689.

Groeneveld, J.C., Gopal, K., George, R.W., Matthee, C.A., 2007. Molecular phylogeny of the spiny lobster genus Palinurus (Decapoda: Palinuridae) with hypotheses on speciation in the NE Atlantic/Mediterranean and SW Indian Ocean. Mol. Phylogenet. Evol. 45, 102-110.

Guindon, S., Gascuel, O., 2003. A simple, fast and accurate method to estimate large phylogenies by maximum-likelihood. Syst. Biol. 52, 696-704.

Hanel, R., Sturmbauer, C., 2000. Multiple recurrent evolution of trophic types northeastern Atlantic and Mediterranean seabreams (Sparidae, Percoidei). J. Mol. Evol. 50, 276-283. doi:10.1007/s002399910032.

Herrán, R., Rejón, C.R., Rejón, M.R., Garrido-Ramos, M.A., 2001. The molecular phylogeny of the Sparidae (Pisces, Perciformes) based on two satellite DNA families. Heredity 87, 691-697.

Hsü, K.J., Montadert, L., Bemoulli, D., Cita, M.B., Erickson, A., Garrison, R.E., Kidd, R.B., M]elierés, F., Müller, C., Wright, R., 1977. History of the mediterranean salinity crisis. Nature 267, 399-403. 
Huelsenbeck, J.P., Ronquist, F., 2001. MRBAYES: bayesian inference of phylogeny. Bioinformatics 17, 754-755.

Kiener, A., Spillman, C.J., 1969. Contribution à l'étude systématique et écologique des athérines des côtes françaises. Mem. Mus. Natl. Hist. Nat., Ser. A 60, 1-74.

Kishino, H., Hasegawa, M., 1989. Evaluation of the maximum likelihood estimate of the evolutionary tree topologies from DNA sequence data, and the branching order in Hominoidea. J. Mol. Evol. 29, 170-179.

Klossa-Kilia, E., Prassa, M., Papasotiropoulos, V., Alahiotis, S., Kilias, G., 2002. Mitochondrial DNA diversity in Atherina boyeri populations as determined by RFLP analysis of three mtDNA segments. Heredity 89, 363-370.

Larkin, M.A., Blackshields, G., Brown, N.P., Chenna, R., McGettigan, P.A., McWilliam, H., Valentin, F., Wallace, I.M., Wilm, A., Lopez, R., Thompson, J.D., Gibson, T.J. Higgins, D.G., 2007. Clustal W and Clustal X version 2.0. Bioinformatics 23, 2947-2948.

Maugé, L.A., 1990. Atherinidae. In: Quire, J.C., Hureau, J.C., Karrer, C., Post, A., Saldanha, L. (Eds.), Check-List of the Fishes of the Eastern Tropical Atlantic (CLOFETA), vol. 2. Paris. pp. 604-605.

Maul, G.E., 1986. Trachichthyidae. In: Whitehead, P., Bauchot, M.L., Hureau, J.C., Nielsen, J., Tortonese, E. (Eds.), Fishes of the North-Eastern Atlantic and the Mediterranean. UNESCO, Paris, pp. 749-752.

Milana, V., Sola, L., Congiu, L., Rossi, A.R., 2008. Mitochondrial DNA in Atherina (Teleostei, Atheriniformes): differencial distribution of na intergenic spacer in lagoon and marine forms of Atherina boyeri. J. Fish Biol. 73, 1216-1227.

Miller, M.A., Pfeiffer, W., Schwartz, T., 2010. Creating the CIPRES science gateway for inference of large phylogenetic trees. In: Proceedings of the Gateway Computing Environments Workshop (GCE). New Orleans, LA, pp. 1-8.

Nelson, J.S., 1994. Fishes of the World. third ed., Jonh Wiley and Sons, New York, p. 600.

Ostellari, L., Barglloni, L., Penzo, E., Patarnello, P., Patarnello, T., 1996. Optimization of single-strand conformation polymorphism and sequence analysis of the mitochondrial control region in Pagellus bogaraveo (Sparidae, Teleostei): rationalized tools in fish population biology. Anim. Genet. 27, 423-427.

Posada, D., 2008. JModeltest: phylogenetic model averaging. Mol. Biol. Evol. 25 1253-1256.

Quignard, J.P., Pras, A., 1986. Atherinidae. In: Whitehead, P., Bauchot, M.L., Hureau, J.C., Nielsen, J., Tortonese, E. (Eds.), Fishes of the North-Eastern Atlantic and the Mediterranean. UNESCO, Paris, pp. 1207-1210.
Ronquist, F., Huelsenbeck, J.P., 2003. MRBAYES 3: bayesian phylogenetic inference under mixed models. Bioinformatics 19, 1572-1574.

Santos, R.S., Porteiro, F.M., Barreiros, J.P., 1997. Marine fishes of the Azores: annotated checklist and bibliography. Bull. Univer. Azores Supplement 1, 244.

Sevilla, R.G., Diez, A., Norén, M., Mouchel, O., Jérôme, M., Verrez-Bagnis, V., van Pelt H., Favre-Krey, L., Krey, G.The Fish Trace Consortium, Bautista, J.M., 2007 Primers and polymerase chain reaction conditions for DNA barcoding teleost fish based on the mitochondrial cytochrome b and nuclear rhodopsin genes. Mol. Ecol. Notes 7, 730-734.

Shimodaira, H., Hasegawa, M., 1999. Multiple comparisons of log-likelihoods with applications to phylogenetic inference. Mol. Biol. Evol. 16, 1114-1116.

Sousa-Santos, C., Robalo, J.I., Collares-Pereira, M.J., Almada, V.C., 2005. Heterozygous indels as useful tools in the reconstruction of DNA sequences and in assessment of ploidy level and genomic constitution of hybrid organisms. DNA Sequence $16,462-467$.

Stamatakis, A., 2006. RAxML-VI-HPC: maximum likelihood-based phylogenetic analyses with thousands of taxa and mixed models. Bioinformatics 22, 26882690.

Swofford, D.L., 2000. PAUP* Phylogenetic Analysis Using Parsimony (*and other methods), Version 4. Sinauer Associates Inc., Sunderland, MA, USA.

Tamura, K., Nei, M., 1993. Estimation of the number of nucleotide substitutions in the control region of mitochondrial DNA in humans and chimpanzees. Mol. Biol. Evol. 10, 512-526.

Trabelsi, M., Gilles, A., Fleury, C., Mâamouri, F., Quignard, J.P., Faure, E., 2002a. Atherina punctata and Atherina lagunae (Pisces, Atherinidae), new species in the Mediterranean Sea. 2. Molecular investigations of three Atherinid species. C. R. Biol. 325, 1119-1128.

Trabelsi, M., Faure, E., Quignard, J.P., Boussaïd, M., Focant, B., Mâamouri, F., 2002b. Atherina punctata and Atherina lagunae (Pisces, Atherinidae), new species in the Mediterranean Sea. 1. Biometric investigations of three Atherinid species. C. R. Biol. 325, 967-975.

von der Heyden, S., Lipinski, M.R., Matthee, C.A., 2007. Mitochondrial DNA analyses of the Cape hakes reveal an expanding, panmictic population for Merluccius capensis and population structuring for mature fish in Merluccius paradoxus. Mol. Phylogenet. Evol. 42, 517-527. 